\title{
Poetry as a means of revolt against the tribe: The experience of poet Suhaym as a model
}

\author{
Abdul Khaliq Esa \\ Dean of the Faculty of Humanities \\ An-Najah National University, Nablus, Palestine \\ Oqab Jabali \\ Director of Language Center \\ An-Najah National University, Nablus, Palestine \\ Kamel Yaseen \\ Ministry of Education and Higher Education \\ Ramallah, Palestine
}

\begin{abstract}
This study traces and identifies the psychological crisis of the veteran, old hand poet, Suhaym, the slave of Bani Al-Hashaas as exposed through his poems. This personality disorder results basically from the poet's inability to socialize and merge into his local society which denies him both his masculinity and recognition as a poet. The study also deals with the repercussions of the poet's psychosis which reduces him to sadism, narcissism, and perversion. As a result, the poet is resolved to get revenge on the tribe through tarnishing the chastity of its women and depicting sexual savagery towards them in his poems. The study results find that these poems are nothing but mere delusions and Suhaym has to pay the price eventually by being burned to death.

Key words: flirting-poetry, perversion, psychosis, revolt, Suhaym, tribe.
\end{abstract}

Cite as: Esa, A., Jabali, O., \& Yaseen, K. (2017). Poetry as a means of revolt against the tribe: The experience of poet Suhaym as a model. Arab World English Journal for Translation \& Literary Studies, 1(3). DOI: http://dx.doi.org/10.24093/awejtls/vol1no3.14 